\title{
Some Comments on "THE NATURE OF CRITICAL THINKING"
}

Professor Reeder's essay is a useful contribution to the ongoing problem of clarifying the relation of "informal logic" to "critical thinking." I have however some points of concern that suggest possible areas of further development.

1. There are I suspect some inevitable areas of contention associated with the concept of critical thinking. Whatever concept one develops will, I believe, reflect one's own ultimate philosophical commitments and so the use of it one ultimately has in mind. Convinced that we live in a bellum omnium contra omnes, one may be persuaded that critical thinking is best viewed as a Machiavellian tool: to defeat one's enemies and to help oneself (including of course the maintenance of useful self-deception). Philosophical sophism, as well as other ideological perspectives condition one's concept of critical thought, explicitly or implicitly. Put another way, the task of defining critical thinking is not a "neutral" but a "dialectical" move.

2. I have some misgivings about the use of the Rogerian model insofar as its seems to implictly legislate how one must engage in dialectic in order to qualify as a truth-seeker, namely humbly, modestly, and softly. I think for example of the powerful dialectic of Marx and Nietzsche. I think also of Marx's comment on the demands of Prussian Censorship:

You admire the enchanting diversity, the inexhaustible wealth of nature. You do not demand that the rose smell like the violet. But the richest of all-the mind-is to exist only in one kind? I am humorous, but the law commands that I write seriously. I am daring, but the law commands that my style be modest. Gray on gray is to be the only permissible color of freedom. Every dewdrop that reflects the sun glitters in an inexhaustible play of colors, but the intellectual sun, in no matter on how many individuals it may be refracted, may produce only one, only the official color! The essential form of the mind is brightness and light, and you want to make the shadow its only appropriate manifestation; it is only to be clad in black, and yet among flowers there are no black ones. The essence of the mind is always the truth itself, and what do you make its essence? Moderation. Only a scamp is moderate, says Goethe, and you want to turn the mind into such a scamp.*

Too great a concern for the fragility of the ego of our in. terlocuter may retard rather than advance truth seeking. Also, when one's audience is varied, one's time limited, the issue crucial, one may have to make a kind of "existential" leap.

3. I have some misgivings, as my remarks above suggest, concerning the notion that a "good argument" will avoid "strong claims" in favor of "smaller claims." (p. 7) May one not make strong claims in order to see how far dialectically one can go with them, to give them a dialectical airing?

* Karl Marx, On Freedom of the Press and Censorship, translated and edited by Saul K. Padover (San Francisco: McGraw-Hill, 1974), p. 92.

Richard W. Paul, Director, Center for Critical Thinking and Moral Critique, Sonoma State University, Rohnert Park, CA 94928

\section{Response to Richard Paul's Comments on "THE NATURE OF CRITICAL THINKING"}

Professor Paul's comments are extremely useful. I wrote this essay with the teaching of critical thinking in mind, but I did not make this restriction sufficiently clear. Professor Paul's comments raise essential issues about critical thinking in the wider sense. I will respond briefly to each of his three points.

Ad 1: I agree that the task of defining critical thinking is a dialectical move. Indeed, I see almost all use of language dialectical in a rather extended sense. My philosophical commitments are reflected in my handling of this task. Professor Paul is correct to point out that my approach is not the only one possible.

Ad 2: My use of Rogerian rhetoric was meant as an example of a useful attitude or approach for teaching critical thinking, rather than as a "model": I did not intend it as a Procrus- tean bed. It is simply a tool I find heuristically useful. Professor Paul is again correct in pointing out the wider context of critical thinking (that is, beyond the classroom), and the resultant protean character of dialectic.

Ad 3: Again Professor Paul is quite correct: I should have qualified my claim. Of course, the dialectical "airing" of ideas is essential to the growth of knowledge. (It is also an indispensable sequel to rhetorical invention.)

Harry P. Reeder, Department of Philosophy, University of Texas at Artington, P.O. Box 19527, Artington, Texas, 76019. 